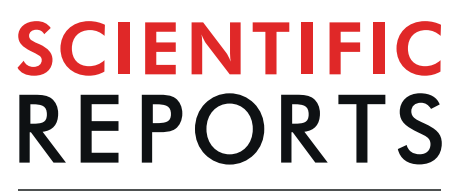

natureresearch

\title{
Reduced-tillage management enhances soil properties and crop yields in a alfalfa-corn rotation: Case study of the Songnen Plain, China
}

\author{
Jishan Chen, Ruifen Zhu, Qiang Zhang, Xiaolei Kong \& Dequan Sun*
}

The reduced-tillage (Rt) has been proposed as a strategy to improve soil organic carbon and soil total nitrogen pools. However, little is known of the role of the reduced-tillage compared with the organic (Org) and conventional (Con) management in the Songnen Plain of China. We studied the $4 \mathrm{yr}$ effect of three management strategies (Con, Org and Rt management) on labile soil organic carbon (C) and nitrogen $(N)$ pools, including variation in mineralizable carbon and nitrogen, microbial biomass carbon and nitrogen, dissolved organic carbon and nitrogen in the rotation of alfalfa-corn established in 2009. Soil characteristics including soil organic carbon (SOC), soil total nitrogen (STN), dissolved organic carbon (DOC), dissolved organic nitrogen (DON), microbial biomass carbon (MBC), and microbial biomass nitrogen (MBN) were quantified in samples collected during the $9 \mathrm{yr}$ rotation of $5 y r$-alfalfa (Medicago sativa L.) followed by 4 yr corn (Zea mays L.). The mineralizable $C$ was increased in the four years, and although not statistically significant, $12 \%$ higher in the fourth year under reduced-tillage than conventional management $\left(268 \mathrm{~kg} \mathrm{ha}^{-1}\right)$. Soil organic $\mathrm{C}$ was increased by $30 \%$ under reducedtillage compared to conventional management (15.5 $\mathrm{Mg} \mathrm{ha}^{-1}$ ). Three management strategies showed similar labile $\mathrm{N}$ pools in the Con and Org management, but differed in the Rt management. Org management showed significantly lesser mineralizable and inorganic $\mathrm{N}$ compared to other strategies, but soil microbial community and comparable crop yield across management strategy in year 4, indicating more efficient $\mathrm{N}$ use for organic than other management strategy. In our conditions, reducedtillage for corn cropping after five years of alfalfa grassland can accumulate labile $\mathrm{C}$ and $\mathrm{N}$ and improve $\mathrm{N}$ utilization to for crop yields in the forage-based rotations. These findings suggest an optimal strategy for using Rt management to enhance soil properties and crop yield in plantation soils and provide a new perspective for understanding the potential role of Rt management in plantation soil.

It is well known that many management practices can improve soil organic carbon (C) and soil total nitrogen (N) pools. Recent studies reported increase in soil organic carbon and soil total nitrogen pools when intensive tillage was changed to reduced- or no-tillage management strategies ${ }^{1,2}$. Strategies to increase soil organic carbon and soil total nitrogen pools may include the use of manure and composts in agro-ecosystem ${ }^{3}$. The effects of different strategies on dynamics of soil organic carbon and nitrogen pools in perennial forage-based rotation, however, is lacking in the Songnen Plain of China.

A typical crop-livestock integrated system in this region of China includes perennial forage crops, mainly alfalfa (Medicago sativa L.) or mixtures of alfalfa and perennial grasses for hay, for five to seven years or until its production decline ${ }^{4,5}$. The period of transition from perennial to annual crops in rotation is critical, due to possible loss of soil organic carbon and nutrients accumulated under alfalfa-grass mixtures for several years with no soil disturbance ${ }^{2}$. Alternatively, the use fresh or composted manure in organic forage production system may contribute to maintain or improve soil fertility status by increasing soil organic carbon and nitrogen pool, resulting 


\begin{tabular}{|c|c|c|c|c|c|c|c|c|c|c|c|c|}
\hline & \multicolumn{3}{|l|}{2014} & \multicolumn{3}{|l|}{2015} & \multicolumn{3}{|l|}{2016} & \multicolumn{3}{|l|}{2017} \\
\hline & $\begin{array}{l}\text { Tmin } \\
\left({ }^{\circ} \mathrm{C}\right)\end{array}$ & $\begin{array}{l}\text { Tmax } \\
\left({ }^{\circ} \mathrm{C}\right)\end{array}$ & \begin{tabular}{|l} 
Rainfall \\
$(\mathbf{m m})$
\end{tabular} & $\begin{array}{l}\text { Tmin } \\
\left({ }^{\circ} \mathrm{C}\right)\end{array}$ & $\begin{array}{l}\text { Tmax } \\
\left({ }^{\circ} \mathrm{C}\right)\end{array}$ & $\begin{array}{l}\text { Rainfall } \\
(\mathrm{mm})\end{array}$ & $\begin{array}{l}\text { Tmin } \\
\left({ }^{\circ} \mathrm{C}\right)\end{array}$ & \begin{tabular}{|l|} 
Tmax \\
$\left({ }^{\circ} \mathrm{C}\right)$
\end{tabular} & $\begin{array}{l}\text { Rainfall } \\
(\mathrm{mm})\end{array}$ & \begin{tabular}{|l|} 
Tmin \\
$\left({ }^{\circ} \mathrm{C}\right)$
\end{tabular} & $\begin{array}{l}\text { Tmax } \\
\left({ }^{\circ} \mathrm{C}\right)\end{array}$ & \begin{tabular}{|l}
$\begin{array}{l}\text { Rainfall } \\
(\mathrm{mm})\end{array}$ \\
\end{tabular} \\
\hline Jan. & -31.0 & -11.0 & 4.0 & -30.0 & -10.0 & 5.0 & -29.0 & -10.4 & 6.0 & -32.0 & -12.0 & 3.0 \\
\hline Feb. & -28.0 & -8.0 & 5.0 & -27.0 & -7.0 & 7.0 & -26.0 & -7.4 & 8.0 & -29.0 & -9.0 & 4.0 \\
\hline Mar. & -25.0 & -5.0 & 5.0 & -24.0 & -4.0 & 6.0 & -23.0 & -4.4 & 7.0 & -26.0 & -6.0 & 4.0 \\
\hline Apr. & -18.0 & 2.0 & 4.0 & -17.0 & 3.0 & 6.0 & -16.0 & 2.6 & 7.0 & -19.0 & 1.0 & 3.0 \\
\hline May. & 0.0 & 20.0 & 25.0 & 1.0 & 21.0 & 30.0 & 2.0 & 20.6 & 31.0 & -1.0 & 19.0 & 24.0 \\
\hline Jun. & 6.0 & 26.0 & 95.0 & 7.0 & 27.0 & 100.0 & 8.0 & 26.6 & 101.0 & 5.0 & 25.0 & 94.0 \\
\hline Jul. & 15.0 & 35.0 & 130.0 & 16.0 & 36.0 & 140.0 & 17.0 & 35.6 & 141.0 & 14.0 & 34.0 & 129.0 \\
\hline Aug. & 10.0 & 30.0 & \begin{tabular}{|l|}
120.0 \\
\end{tabular} & 11.0 & 31.0 & 120.0 & 12.0 & 30.6 & 121.0 & 9.0 & 29.0 & \begin{tabular}{|l|}
119.0 \\
\end{tabular} \\
\hline Sep. & 6.0 & 26.0 & 50.0 & 7.0 & 27.0 & 60.0 & 8.0 & 26.6 & 51.0 & 5.0 & 25.0 & 49.0 \\
\hline Oct. & -5.0 & 15.0 & 15.0 & -4.0 & 16.0 & 20.0 & -3.0 & 15.6 & 21.0 & -6.0 & 14.0 & 28.0 \\
\hline Nov. & -20.0 & 0.0 & 4.0 & -19.0 & 1.0 & 5.0 & -18.0 & 0.6 & 6.0 & -21.0 & -1.0 & 3.0 \\
\hline Dec. & -29.0 & -9.0 & 2.0 & -28.0 & -8.0 & 2.0 & -27.0 & -8.4 & 3.0 & -30.0 & -10.0 & 1.0 \\
\hline
\end{tabular}

Table 1. Monthly total precipitation $(\mathrm{mm})$ and average monthly maximum and minimum temperature $\left({ }^{\circ} \mathrm{C}\right)$ from 2014 to 2017 year. Notes: $T \mathrm{~min}=$ minimum temperature and $\mathrm{Tmax}=$ maximum temperature.

in improved agroecosystem performance. In organic production system, soil organic carbon and nutrient accumulation are affected by manure or compost application, which also contributes to increasing biomass, activity and diversity of soil microorganisms, as well as to soil microbially mediated soil-building processes ${ }^{6}$. It can also contribute to reduced $\mathrm{N}$ loss compared with the conventional management system ${ }^{7}$. But organic production also relies on intensive tillage to cultivate crops due to a lack of alternatives for weed control ${ }^{8}$.

A major challenge in conventional as well as organic management of perennial forage-annual crop production system is loss of soil organic carbon and nutrients due to intensive tillage to establish annual crops in rotation. Reduced tillage management can improve soil quality by conserving soil organic carbon ${ }^{9,10}$, increasing crop residue inputs ${ }^{11}$, augmenting microbial biomass and activity ${ }^{12}$, and increasing root biomass production ${ }^{2}$. Studies show that increase in fine roots and microbial biomass is strongly correlated with increase in soil organic carbon content in agroecosystem ${ }^{2,13}$. The agronomic and soil quality benefits in perennial forage because soil disturbance is dramatically reduced during the conversion process. The benefit of perennial forage-annual crop includes the increase soil organic carbon and nitrogen, but also the possibility of producing equivalent or greater yields compared with the conventional management ${ }^{14,15}$. For example, organic forage-grain crop rotations showed comparable crop yield and higher profit than conventional crop rotations in three long-term forage production strategy in Canada ${ }^{16}$. Similarly, organic and conventional management demonstrated little difference in crop yield in long-term cropping management experiments in Pennsylvania ${ }^{17}$ and no difference in vegetable production in California ${ }^{18}$. Reduced-tillage also increases crop production and profitability by minimizing soil disturbance, improving soil quality, and creating more consistent soil environments for microbial growth and activity ${ }^{19-22}$. Hence, understanding the seasonal and interannual dynamics of labile soil organic $\mathrm{C}$ and $\mathrm{N}$ pools, including variation in mineralizable $\mathrm{C}$ and $\mathrm{N}$, microbial biomass $\mathrm{C}$ and $\mathrm{N}$, dissolved organic $\mathrm{C}$ and $\mathrm{N}$ under various cropping system can help producers design more sustainable cropping management in the Songnen Plain of China.

We evaluated the long-term $(4 \mathrm{yr})$ effect of three management strategies that included organic and reduced-tillage management on soil properties and crop yield compared with conventional management in the Songnen Plain of China. The objective of this study was to (1) quantify the impact of three management strategies on soil organic carbon and nitrogen pools, and crop and forage production, (2) determine which management strategies that enhance soil organic carbon and nitrogen pools, and crop and forage production. It was hypothesized that labile soil organic carbon and nitrogen pools would increase more rapidly under reduced-tillage and organic management system compared with the conventional system. In addition, greater yields of perennial forages and corn grain could be as result of increased in soil organic $\mathrm{C}$ and $\mathrm{N}$ pools in a generally low fertility soils of the Songnen Plain, China.

\section{Material and Methods}

Ethics statement. No specific permissions were required for the described field studies and for these locations/activities. The location is not privately owned or protected in any way. The studies did not involve endangered or protected species.

Experimental site. The field experiment was carried out at the Frigid Forage Research Station located at Lanxi county of Songnen Plain, runned by Heilongjiang Academy of Agricultural Sciences (HASS). The station has an altitude of $160 \mathrm{~m}$, longitude of $125^{\circ} 28^{\prime} 24^{\prime \prime} \mathrm{E}$, latitude of $46^{\circ} 32^{\prime} 17^{\prime \prime} \mathrm{N}$ in Northeast China. The climate is classifed as a typical chillness semiwetness monsoon environment (Table 1). The mean annual precipitation is $469.7 \mathrm{~mm}$, and the mean air temperature is $5.3^{\circ} \mathrm{C}$, with a maximum temperature of $31.2^{\circ} \mathrm{C}$ (July) and a minimum temperature of $-25.2^{\circ} \mathrm{C}$ (January), respectively. The total yearly sunshine duration is 2713 hours and the no frost period is 130 days.

The $9 \mathrm{yr}$ rotation of alfalfa (Medicago sativa L.) (5yr) - corn (Zea mays L.) (4 yr) began in 2009 with intensively management including the variety, artificial ploughing, weeding and mowing. Beginning of establishing the alfalfa grassland, all seeds were drilled uniformly with a commercial inoculant of Sinorhizobium. After seeding, 


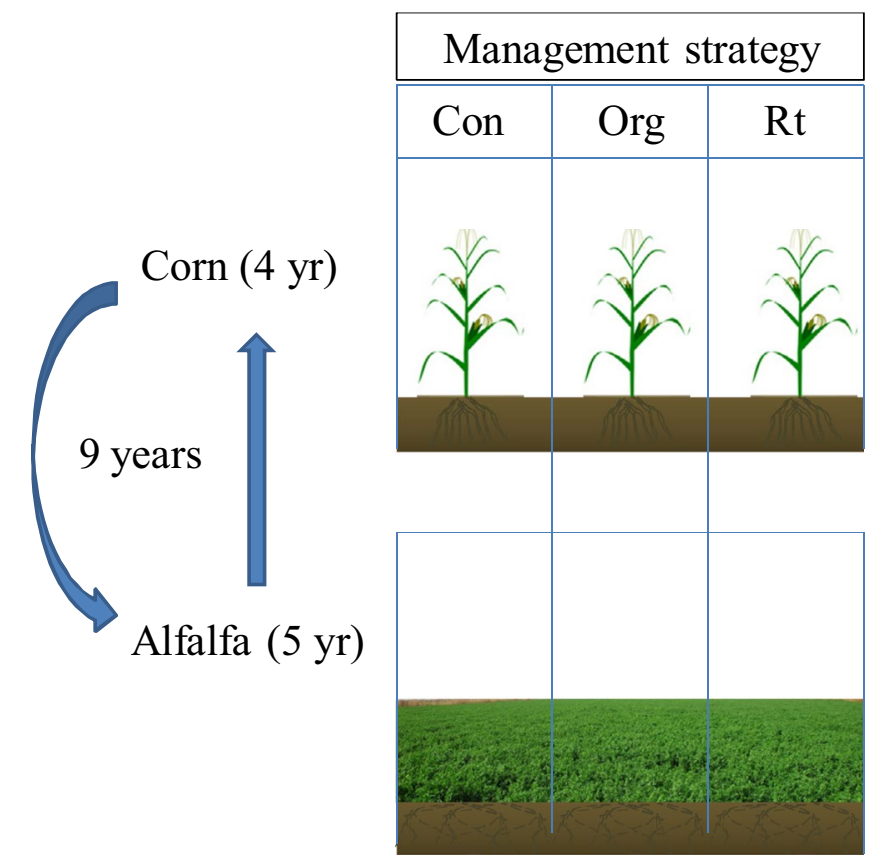

Figure 1. The $9 \mathrm{yr}$ rotation of alfalfa (Medicago sativa L.) (5yr) - corn (Zea mays L.) (4yr) began in 2009. Crop rotations included a homogeneity of alfalfa for the first five years (2009-2013), followed by corn from the sixth year (2014-2017).

the experiment was reserved to protect the experimental rows from interferential damage. The alfalfa was only used for cutting during the experiment period. Crop rotations included a homogeneity of alfalfa for the first five years (2009-2013), followed by corn from the sixth year (2014-2017) (Fig. 1). The plant density of alfalfa was $1136 \times 10^{4}$ plants $\mathrm{ha}^{-1}$ and that for corn was $5.3 \times 10^{4}$ seeds ha ${ }^{-1}$. The alfalfa and corn seed were provided by HASS. These varieties were chosen due to its high adaptability and existing widespread use in the Songnen Plain of China. In this study, the soil is dark loam (mostly Chernozem, FAO Taxonomy) with high melanic humus. The experimental area had an average soil $\mathrm{pH}$ of 7.82 , an average soil organic matter content of $6.04 \%$, total $\mathrm{N}$ content of $0.34 \%$; the contents of $\mathrm{NO}_{3}{ }^{-} \mathrm{N}$ was $4.35 \%$, the contents of $\mathrm{NH}_{4}{ }^{+}-\mathrm{N}$ was $6.81 \%$ and available $\mathrm{P}$ was $22.35 \mathrm{ppm}$ (Olsen method $)^{23}$.

Experimental design and treatments. In May 2014, 12 plots of $50 \times 50 \mathrm{~m}$ were established in the rotation of alfalfa-corn. In order to different from the conventional management strategies of annual inorganic fertilization, the randomized complete block design was used. Treatments included (1) organic management (Org), annual organic fertilization with moldboard plowing condition; (2) reduced-tillage management (Rt), Minimum tillage condition with leaving $<15 \%$ residue cover (Conservation Technology Information Center, CTIC) ${ }^{24}$ and without annual fertilization and (3) conventional management (Con), annual inorganic fertilization with moldboard plowing condition (control). Annual organic and inorganic fertilization were applied in Org and Con, and residue cover applications in Rt. Organic fertilization was applied at $45 \mathrm{t} \mathrm{ha}^{-1}$ of cow dung with $3.45 \mathrm{~g} \mathrm{~kg}^{-1}$ $\mathrm{N}, 0.18 \mathrm{~g} \mathrm{~kg}^{-1} \mathrm{P}$ and $1.56 \mathrm{~g} \mathrm{~kg}^{-1} \mathrm{~K}$ in Org. Inorganic fertilization was fertilized at $337.5 \mathrm{~kg} \mathrm{ha}^{-1}$ of the compound fertilizer with ratio of 24-7-9 for nitrogen, phosphorus and potassium in Con. Three replicate plots per treatment were established under rainfed condition. During establishing the experimental plots, each plot is 10 meter long and 5 meter wide with inter-row spacing of $60 \mathrm{~cm}$ for corn. All seeds were drilled uniformly with three differents management strategies. Soils preparation for conventional and organic management strategy consisted in plowing with a moldboard, disking, and cultivating to a depth of $20 \mathrm{~cm}$ (total five tillage passes), with incorporation crop residues into soils, leaving $<15 \%$ residue cover on the soil surface. The tillage of reduced-tillage management was designed to loosen the surface without inverting the soil ${ }^{24}$ and done with a pass of a Landstar (Kuhn Krause, Inc., Hutchinson, KS), a five-step tillage system that discs, cultivates, and uniformly distributes residues in the seedbed $(0-20 \mathrm{~cm})$ and on the soil surface. Before the establishment of the experiment, the entire area was managed under conventionally tilled continuous corn for at least ten years. The soil of the experimental field was not tilled for five years after establishment of the alfalfa grassland at all management strategy.

Soil properties and microbial biomass determination. Soil from 16 sampling points were collected during spring, early and late summer, and fall seasons at each plot from 2014 to 2017 year. Depth of soil sample collection was $0-30 \mathrm{~cm}$ and three layers at soil profiles was sampled, i.e., $0-10 \mathrm{~cm}, 10-20 \mathrm{~cm}$, and $20-30 \mathrm{~cm}$. Soil core $(3.2-\times 15-\mathrm{cm})$ were collected from each transect, composited, thoroughly homogenized, and a $\sim 500 \mathrm{~g}$ subsamples were taken to the laboratory. Immediately after the collection samples were kept in a cooler, and stored in a $4{ }^{\circ} \mathrm{C}$ refrigerator prior laboratory analyses. All soil were sieved through a $2 \mathrm{~mm}$ sieve, and subsamples were stored at $-80^{\circ} \mathrm{C}$ until further molecular analysis. The others were used to determine the properties of the soil. 
Analysis of mineralizable $\mathrm{C}$ and $\mathrm{N}$, inorganic $\mathrm{N}$, dissolved organic carbon (DOC), dissolved organic nitrogen (DON), microbial biomass carbon (MBC), and microbial biomass nitrogen (MBN) were performed. Soil pH, electrical conductivity (EC), soil organic carbon (SOC), and soil total nitrogen (STN) were determined in samples collected in spring 2014 and fall 2017. The soil texture was determined in soil samples collected in spring 2014. To measure soil bulk density $(\mathrm{Db})$ a separate set of soil samples were collected from sampling points along each transect using a $2.1 \mathrm{~cm}$ diameter bulk density probe.

DNA extraction and bioinformatics analysis. Total DNA was extracted from $0.25 \mathrm{~g}$ of soil using the Ezup Column Soil DNA Purification Kit (Sangon Biotech, Beijing, China) according to the manufacturer's instructions. The $16 \mathrm{~S}$ rRNA amplicons were sequenced using the Illumina Miseq platform at Novogene (Beijing, China). Briefly, sequence reads were extracted, primers were removed, and the sequences were trimmed to remove low quality sequences. The trimmed and unique sequences were used to define the number of operational taxonomic units (OTUs) at the $97 \%$ similarity level. All is to estimate soil microbial community.

Aboveground biomass and yield measurement. Samples of aboveground biomass of alfalfa-grasses were collected two times in 2009 (July and September) and three times in 2010-2013 (June, August, and September) at the time of hay harvest, which was typically done at $10 \%$ flowering of alfalfa. Aboveground biomass samples were collected using a Hege 212 forage plot harvester. Biomass samples were field dried to $\sim 12 \%$ moisture, and approximately 500 -g subsamples were brought to the laboratory, weighed, oven dried at $70^{\circ} \mathrm{C}$ for $48 \mathrm{~h}$, and weighed again to estimate the dry biomass. The sum of aboveground biomass harvested multiple times within a year was considered the annual aboveground biomass. To estimate crop yield every year (2014-2017), corn cobs were allowed dry to $\sim 15 \%$ moisture in the field and the total area harvested ( 0.81 ha per plot) using a John Deer combine harvester, $\sim 100 \mathrm{~g}$ subsamples were wet weighed, oven dried at $70^{\circ} \mathrm{C}$ for $48 \mathrm{~h}$, and weighed.

Laboratory analysis methods. The quantification of nitrate $\left(\mathrm{NO}_{3}^{-}\right)$and ammonium $\left(\mathrm{NH}_{4}^{+}\right)$was used to determine soil inorganic $\mathrm{N}^{25}$. Soil mineralizable $\mathrm{C}$ was analyzed by aerobic incubation for 14 days in a litter glass $\mathrm{jar}^{26}$. The incubated samples were used to analyse soil inorganic $\mathrm{N}$ and determine mineralizable N. Similarly, DOC, and TDN were determined by the method reported by Ghimire et al. ${ }^{2}$. Automatic acidification and the sparging process within the instrument were used to remove the dissolved inorganic C. DON values were calculated by discounting inorganic $\mathrm{N}$ from TDN. Fumigation extraction process was used to determine soil MBC and $\mathrm{MBN}^{27}$ adopting the efficiency factor 0.41 for both $\mathrm{MBC}$ and $\mathrm{MBN}$ calculations ${ }^{28}$ without subtracting to non-fumigated control ${ }^{29}$. The hydrometer method was used to determine soil particle-size distribution ${ }^{30}$, electrode for $\mathrm{pH}$ and $\mathrm{EC} \mathrm{by}^{31}$, dry combustion for total C and N (EA1100 Soil C/N analyzer, Carlo Erba Instruments, Milan, Italy), pressure calcimeter for inorganic $\mathrm{C}^{31}$, and the gravimetric technique for soil moisture. Total $\mathrm{C}$ minus inorganic $\mathrm{C}$ was considered the SOC. The core method was used to demine soil bulk density ${ }^{32}$. The V4 hypervariable regions of bacterial 16S rRNA genes were selected for amplification using the primer pair $515 \mathrm{f} / 806 \mathrm{r}^{33}$. PCR conditions and products were as described previously ${ }^{34}$.

Statistical analysis. Data were conducted using SPSS18.0 for Windows (SPSS Inc., Chicago, Illinois). The split plot in time analysis were used for analyzing soil characteristics such as mineralizable $\mathrm{C}$ and N, DOC, DON, $\mathrm{MBC}$, and MBN considering management strategy as a fixed effect, season and year as repeated measurements, and replication as a random term in the model. In this analysis, the year effect was highly significant $(P<0.001)$, but showed a weak relation to effects of management strategy $(P>0.05)$. Thus, all data were re-analyzed for management strategy, season, and management strategy $\times$ season interaction within a year considering management strategy as a fixed effect, season as a repeated measure, and replication as a random term in the model (Table 2). In addition, soil microbial community was analyzed by the vegan package in $\mathrm{R}$.

\section{Results}

Effect of management on the SOC. SOC was affected only by management strategy $\times$ year interaction (Table 2). Management strategy showed differences in soil mineralizable C in the four years (Table 3). Rt management showed greater mineralizable C compared to Con and Org management in years 1-4, following a similar trend (Rt $>$ Org $>$ Con) throughout the evaluated period. In the year 2017, mineralizable $\mathrm{C}$ in the soil was affected by management strategy $\times$ season interaction (Table 2), with greater contents under Rt and lower under Org management compared with Con management in early summer sampling. Soil DOC and MBC contents changed little among management strategy throughout the study, but DOC and MBC contents were significantly increased over the years in all three management strategies (Tables 4-6).

Effect of management on the $\mathbf{N}$ pools. Mineralizable $\mathrm{N}$ content in the soil was similar among the management strategy in the first three years, but increased as experimental period progress (Table 4). In year 4, however, soil mineralizable $\mathrm{N}$ was significantly lesser for Con compared to Org and Rt management. The mineralizable $\mathrm{N}$ content in year 4 was affected by management strategy $\times$ season interaction (Table 2 ). Greater soil mineralizable $\mathrm{N}$ content was found at Org management compared to Con in the spring season, but the concentration was continuously reduced toward summer and fall seasons in 2017 year (Table 7). STN, pH, EC and bulk density were not affected by management strategy, year or management strategy $\times$ year interaction (Table 2 ). Inorganic $\mathrm{N}$ contents in the soil were consistent among the management strategy in year 1, 2 and year 3 (Table 4), but the DON was not affected by management strategy (Table 2). The Org system showed consistently low soil inorganic $\mathrm{N}$ throughout the growing seasons, while in the Con and Rt management were sharply increased in early summer and decreased gradually toward late summer and fall (Table 7). 


\begin{tabular}{|c|c|c|c|c|c|}
\hline \multirow[b]{2}{*}{ Parameters } & \multirow[b]{2}{*}{ Effects } & \multicolumn{4}{|l|}{ Year } \\
\hline & & 2014 & 2015 & 2016 & 2017 \\
\hline \multirow{3}{*}{ Mineralizable C } & Management (M) & 0.05 & 0.01 & 0.05 & 0.04 \\
\hline & Season (S) & 0.03 & $<0.01$ & $<0.01$ & $<0.01$ \\
\hline & $\mathrm{M} \times \mathrm{S}$ & 0.07 & 0.47 & 0.58 & 0.01 \\
\hline \multirow{3}{*}{ Mineralizable N } & $\mathrm{M}$ & 0.48 & 0.23 & 0.84 & 0.08 \\
\hline & S & 0.01 & $<0.01$ & 0.01 & 0.01 \\
\hline & $\mathrm{M} \times \mathrm{S}$ & 0.32 & 0.09 & 0.91 & $<0.01$ \\
\hline \multirow{3}{*}{ Inorganic $\mathrm{N}$} & $\mathrm{M}$ & 0.08 & 0.02 & 0.99 & $<0.01$ \\
\hline & S & $<0.01$ & 0.01 & $<0.01$ & $<0.01$ \\
\hline & $\mathrm{M} \times \mathrm{S}$ & 0.29 & 0.26 & 0.18 & $<0.01$ \\
\hline \multirow{3}{*}{ DOC } & $\mathrm{M}$ & 0.29 & 0.22 & 0.18 & 0.35 \\
\hline & S & 0.05 & $<0.01$ & $<0.01$ & $<0.01$ \\
\hline & $\mathrm{M} \times \mathrm{S}$ & 0.27 & 0.09 & 0.03 & 0.52 \\
\hline \multirow{3}{*}{ DON } & $\mathrm{M}$ & 0.29 & 0.39 & 0.13 & 0.48 \\
\hline & $\mathrm{S}$ & 0.01 & $<0.01$ & $<0.01$ & 0.28 \\
\hline & $\mathrm{M} \times \mathrm{S}$ & 0.38 & 0.39 & 0.056 & $<0.01$ \\
\hline \multirow{3}{*}{ MBC } & $\mathrm{M}$ & 0.48 & 0.02 & 0.19 & 0.49 \\
\hline & S & 0.01 & $<0.01$ & $<0.01$ & $<0.01$ \\
\hline & $\mathrm{M} \times \mathrm{S}$ & 0.39 & 0.03 & 0.35 & 0.03 \\
\hline \multirow{3}{*}{ MBN } & M & 0.07 & 0.01 & 0.02 & 0.36 \\
\hline & S & 0.05 & $<0.01$ & $<0.01$ & 0.25 \\
\hline & $\mathrm{M} \times \mathrm{S}$ & 0.47 & 0.055 & 0.49 & 0.06 \\
\hline \multicolumn{2}{|c|}{ One time measurement } & \multicolumn{2}{|c|}{ Management (M) } & Year $(\mathbf{Y})$ & $\mathbf{M} \times \mathbf{Y}$ \\
\hline \multicolumn{2}{|l|}{ SOC } & \multicolumn{2}{|l|}{0.46} & 0.59 & $<0.01$ \\
\hline \multicolumn{2}{|l|}{ STN } & \multicolumn{2}{|l|}{0.69} & 0.39 & 0.69 \\
\hline \multicolumn{2}{|l|}{$\mathrm{pH}$} & \multicolumn{2}{|l|}{0.17} & 0.16 & 0.15 \\
\hline \multicolumn{2}{|l|}{ EC } & \multicolumn{2}{|l|}{0.23} & 0.51 & 0.67 \\
\hline \multicolumn{2}{|l|}{$\mathrm{Db}$} & \multicolumn{2}{|l|}{0.19} & 0.15 & 0.89 \\
\hline
\end{tabular}

Table 2. Analysis of variance result ( $P$-values) for labile soil organic carbon and nitrogen pools and other soil properties under conventional (Con), organic (Org) and reduced-tillage (Rt) management strategy. Notes: $\mathrm{DOC}=$ dissolved organic carbon, $\mathrm{DON}=$ dissolved organic nitrogen, $\mathrm{MBC}=$ microbial biomass carbon, and $\mathrm{MBN}=$ microbial biomass nitrogen, $\mathrm{SOC}=$ soil organic carbon, $\mathrm{STN}=$ soil total nitrogen, $\mathrm{EC}=$ electrical conductivity and $\mathrm{Db}=$ bulk density. One time measurement parameters were measured at the beginning (Apr. 2014) and end (Sep. 2017) of the study.

Seasonal variations of the SOC and N pools. Seasonal trend of labile SOC components and N pools in year 4 (Tables 2-4), we observed gradual decreases in mineralizable $\mathrm{C}$ from summer to fall seasons under reduced-tillage with no soil disturbance for corn cropping and sharper decreases under the tilled treatment. Management strategy showed different seasonal patterns in mineralizable and inorganic $\mathrm{N}$ content, with greater values during summer under conventional and reduced-tillage but not for organic management. The DOC and $\mathrm{MBC}$ increased, and DON and MBN decreased across all management strategy (Tables 3 and 4). Consistently low soil inorganic $\mathrm{N}$ was observed throughout the study with different seasonal trends for management strategy (Table 7), indicating difference in accumulation of inorganic $\mathrm{N}$ in soils receiving organic and chemical fertilizers.

Effect of management on aboveground biomass yield. Aboveground biomass yield was similar across the management strategy in the first year (Table 8), significantly greater under Rt than under Con and Org management in the second and third year. Management strategy resulted in different biomass yield in fourth year. The experiment was carried out for four consecutive years $(2014,2015,2016$ and 2017), where average annual yield from different years was different and variable. In four growing seasons, the best year for aboveground biomass yield was 2017 year followed by 2016 year for Rt management, while the smallest yield was found in 2014 year for Con management.

Effect of management on Soil microbial community. More than 26000 valid reads were obtained for each replicate treatment. The median sequence length of each read was $255 \mathrm{bp}$. A total of 47285 OTUs was detected using 97\% identity as the cutoff. At the phylum level, the number of Phylum in the Org and Rt management was 22 and 23, which was higher than the number of Phylum in the Con management (Table 9). The dominant phyla were Proteobacteria (32.5\%), Acidobacteria (22.6\%), Gemmatimonadetes (11.5\%), and Chloroflexi (7.6\%) (Fig. 2). In the three management strategies, the relative abundance of Acidobacteria was lower in the Rt and Org management than in the control (Con), whereas Gemmatimonadetes exhibited the opposite trends. The relative abundance of Proteobacteria and Actinobacteria was higher in the Rt management than in the Org 


\begin{tabular}{|c|c|c|c|c|c|c|c|c|c|c|c|c|}
\hline & \multicolumn{4}{|c|}{ Mineralizable C $\left(\mathrm{kg} \mathrm{ha}^{-1}\right)$} & \multicolumn{4}{|c|}{ DOC $\left(\mathrm{kg} \mathrm{ha}^{-1}\right)$} & \multicolumn{4}{|c|}{$\operatorname{MBC}\left(\mathrm{kg} \mathrm{ha}^{-1}\right)$} \\
\hline & 2014 & 2015 & 2016 & 2017 & 2014 & 2015 & 2016 & 2017 & 2014 & 2015 & 2016 & 2017 \\
\hline Con & $181.2 \pm 1.12 \mathrm{~b}$ & $210.2 \pm 2.13 \mathrm{~b}$ & $220.1 \pm 1.14 \mathrm{~b}$ & $230.5 \pm 3.17 \mathrm{c}$ & $161.3 \pm 1.06 \mathrm{a}$ & $160.2 \pm 2.14 \mathrm{~b}$ & $160.5 \pm 1.02 \mathrm{~b}$ & $170.8 \pm 1.33 \mathrm{~b}$ & $460.9 \pm 1.42 \mathrm{a}$ & $410.6 \pm 1.12 \mathrm{~b}$ & $400.6 \pm 1.19 \mathrm{c}$ & $455.7 \pm 1.88 \mathrm{~b}$ \\
\hline Org & $180.4 \pm 1.08 \mathrm{~b}$ & $200.3 \pm 2.16 \mathrm{~b}$ & $240.6 \pm 1.15 b$ & $270.3 \pm 3.16 \mathrm{~b}$ & $160.2 \pm 1.02 \mathrm{a}$ & $200.2 \pm 1.12 \mathrm{a}$ & $180.6 \pm 1.82 \mathrm{~b}$ & $280.2 \pm 1.67 \mathrm{a}$ & $500.5 \pm 1.85 \mathrm{a}$ & $720.9 \pm 1.77 \mathrm{a}$ & $880.0 \pm 1.33 \mathrm{~b}$ & $890.1 \pm 1.57 \mathrm{a}$ \\
\hline Rt & $200.6 \pm 1.09 \mathrm{a}$ & $320.5 \pm 1.02 \mathrm{a}$ & $370.8 \pm 1.11 \mathrm{a}$ & $390.9 \pm 3.19 \mathrm{a}$ & $162.1 \pm 2.11 \mathrm{a}$ & $210.9 \pm 3.19 \mathrm{a}$ & $290.5 \pm 3.11 \mathrm{a}$ & $300.8 \pm 3.09 \mathrm{a}$ & $690.9 \pm 3.15 \mathrm{a}$ & $900.7 \pm 3.44 a$ & $910.9 \pm 3.67 a$ & $928.6 \pm 3.129 \mathrm{a}$ \\
\hline
\end{tabular}

Table 3. Labile soil organic carbon under conventional (Con), organic (Org) and reduced-tillage (Rt) management from 2014 to 2017 year. Notes: Means are shown that means with same letter within a year are not significantly different $(P=0.05)$. $\mathrm{DOC}=$ dissolved organic carbon and $\mathrm{MBC}=$ microbial biomass carbon.

\begin{tabular}{|c|c|c|c|c|c|c|c|c|c|c|c|c|c|c|c|c|}
\hline & \multicolumn{4}{|c|}{ Mineralizable $\mathrm{N}\left(\mathrm{kg} \mathrm{ha}^{-1}\right)$} & \multicolumn{4}{|c|}{ DON $\left(\mathrm{kg} \mathrm{ha}^{-1}\right)$} & \multicolumn{4}{|c|}{$\operatorname{MBN}\left(\mathrm{kg} \mathrm{ha}^{-1}\right)$} & \multicolumn{4}{|c|}{ Inorganic $\mathbf{N}\left(\mathrm{kg} \mathrm{ha}^{-1}\right)$} \\
\hline & 2014 & 2015 & 2016 & 2017 & 2014 & 2015 & 2016 & 2017 & 2014 & 2015 & 2016 & 2017 & 2014 & 2015 & 2016 & 2017 \\
\hline Con & $\begin{array}{l}13.2 \pm \\
0.13 \mathrm{a}\end{array}$ & $\begin{array}{l}28.2 \pm \\
0.23 \mathrm{a}\end{array}$ & $\begin{array}{l}23.2 \pm \\
0.18 \mathrm{a}\end{array}$ & $\begin{array}{l}22.9 \pm \\
0.19 \mathrm{c}\end{array}$ & $\begin{array}{l}9.2 \pm \\
0.03 \mathrm{a}\end{array}$ & $\begin{array}{l}14.3 \pm \\
0.15 \mathrm{a}\end{array}$ & $\begin{array}{l}31.5 \pm \\
0.18 \mathrm{a}\end{array}$ & $\begin{array}{l}56.2 \pm \\
0.16 \mathrm{a}\end{array}$ & $60.1 \pm 0.17 \mathrm{a}$ & $70.2 \pm 0.12 b$ & $80.8 \pm 0.18 b$ & $90.4 \pm 0.14 \mathrm{a}$ & $7.9 \pm 0.10 \mathrm{a}$ & $15.0 \pm 0.10 \mathrm{a}$ & $19.6 \pm 0.17 \mathrm{a}$ & $10.8 \pm 0.12 \mathrm{c}$ \\
\hline Org & $\begin{array}{l}15.4 \pm \\
0.16 \mathrm{a}\end{array}$ & $\begin{array}{l}27.9 \pm \\
0.12 \mathrm{a}\end{array}$ & $\begin{array}{l}45.8 \pm \\
0.11 \mathrm{a}\end{array}$ & $\begin{array}{l}37.6 \pm \\
0.13 \mathrm{~b}\end{array}$ & $\begin{array}{l}7.1 \pm \\
0.02 \mathrm{a}\end{array}$ & $\begin{array}{l}16.1 \pm \\
0.18 \mathrm{a}\end{array}$ & $\begin{array}{l}35.1 \pm \\
0.14 \mathrm{a}\end{array}$ & $\begin{array}{l}53.9 \pm \\
0.12 \mathrm{a}\end{array}$ & $50.9 \pm 0.10 \mathrm{a}$ & $70.5 \pm 0.17 \mathrm{~b}$ & $190.5 \pm 0.19 b$ & $200.5 \pm 0.18 \mathrm{a}$ & $6.7 \pm 0.13 \mathrm{a}$ & $11.7 \pm 0.12 \mathrm{a}$ & $16.7 \pm 0.18 \mathrm{a}$ & $28.9 \pm 0.15 b$ \\
\hline Rt & $\begin{array}{l}18.6 \pm \\
0.17 \mathrm{a}\end{array}$ & $\begin{array}{l}34.7 \pm \\
0.23 \mathrm{a}\end{array}$ & $\begin{array}{l}47.7 \pm \\
0.16 \mathrm{a}\end{array}$ & $\begin{array}{l}60.9 \pm \\
0.11 \mathrm{a}\end{array}$ & $\begin{array}{l}10.5 \pm \\
0.03 \mathrm{a}\end{array}$ & $\begin{array}{l}19.5 \pm \\
0.17 \mathrm{a}\end{array}$ & $\begin{array}{l}46.9 \pm \\
0.10 \mathrm{a}\end{array}$ & $\begin{array}{l}65.7 \pm \\
0.18 \mathrm{a}\end{array}$ & $80.6 \pm 0.16 a$ & $110.8 \pm 0.15 a$ & $280.7 \pm 0.15 a$ & $280.9 \pm 0.15 \mathrm{a}$ & $5.9 \pm 0.16 \mathrm{a}$ & $20.7 \pm 0.14 \mathrm{a}$ & $22.8 \pm 0.12 \mathrm{a}$ & $40.8 \pm 0.19 a$ \\
\hline
\end{tabular}

Table 4. Nitrogen pools under conventional (Con), organic (Org) and reduced-tillage (Rt) management from 2014 to 2017 year. Notes: Means are shown that means with same letter within a year are not significantly different $(P=0.05)$. DON $=$ dissolved organic nitrogen and $\mathrm{MBN}=$ microbial biomass nitrogen.

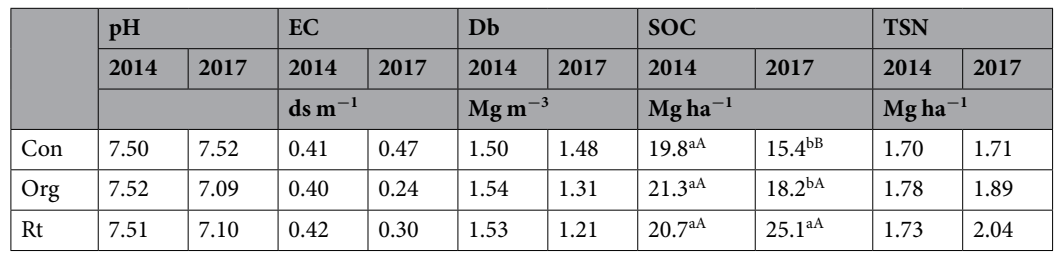

Table 5. Soil properties under conventional (Con), organic (Org) and reduced-tillage (Rt) management at the beginning (2014 year) and end (2017 year) of the study. Notes: Means are shown that means with same letter within a year are not significantly different $(P=0.05) . \mathrm{EC}=$ electrical conductivity, $\mathrm{Db}=$ bulk density, $\mathrm{SOC}=$ soil organic carbon, and STN $=$ soil total nitrogen.

\begin{tabular}{|c|c|c|c|c|c|c|c|c|}
\hline & \multicolumn{4}{|c|}{ Mineralizable C $\left(\mathrm{kg} \mathrm{ha}^{-1}\right)$} & \multicolumn{4}{|l|}{$\operatorname{MBC}\left(\mathrm{kg} \mathrm{ha}^{-1}\right)$} \\
\hline & Spring & Early summer & Late summer & Fall & Spring & Early summer & Late summer & Fall \\
\hline Con & $510.7 \pm 22.13 \mathrm{a}$ & $280.5 \pm 20.15 b$ & $170.6 \pm 12.10 \mathrm{a}$ & $100.8 \pm 8.15 \mathrm{a}$ & $690.8 \pm 32.54 \mathrm{~b}$ & $1380.6 \pm 42.18 \mathrm{~b}$ & $680.3 \pm 26.44 b$ & $1030.9 \pm 52.66 \mathrm{a}$ \\
\hline Org & $560.5 \pm 25.17 \mathrm{a}$ & $160.8 \pm 20.17 \mathrm{c}$ & $160.8 \pm 11.16 \mathrm{a}$ & $120.3 \pm 9.16 a$ & $790.9 \pm 32.21 \mathrm{a}$ & $1400.8 \pm 32.77 \mathrm{ab}$ & $1000.4 \pm 25.19 \mathrm{a}$ & $1180.6 \pm 61.43 a$ \\
\hline Rt & $460.79 \pm 26.10 \mathrm{a}$ & $370.1 \pm 21.18 \mathrm{a}$ & $180.9 \pm 13.14 \mathrm{a}$ & $130.8 \pm 7.19 \mathrm{a}$ & $750.8 \pm 30.14 \mathrm{ab}$ & $1580.9 \pm 42.63 \mathrm{a}$ & $920.8 \pm 21.87 \mathrm{a}$ & $1120.4 \pm 53.17 \mathrm{a}$ \\
\hline
\end{tabular}

Table 6. Labile soil organic carbon influenced by management strategy $\times$ season interaction in 2017 under conventional (Con), organic (Org) and reduced-tillage (Rt) management. Notes: Means are shown that means with same letter within a season are not significantly different $(P=0.05) . \mathrm{MBC}=$ microbial biomass carbon.

\begin{tabular}{|l|l|l|l|l|l|l|l|l|}
\hline \multirow{3}{*}{} & \multicolumn{9}{|l}{ Mineralizable N $\left(\mathbf{k g ~ h a}^{-\mathbf{1}}\right)$} & \multicolumn{4}{l|}{ Inorganic N $\left(\mathbf{k g ~ \mathbf { ~ } ^ { - 1 }}\right)$} \\
\cline { 2 - 9 } & Spring & Early summer & late summer & Fall & Spring & $\begin{array}{l}\text { Early } \\
\text { summer }\end{array}$ & late summer & Fall \\
\hline Con & $60.5 \pm 1.15^{\mathrm{a}}$ & $90.2 \pm 2.34^{\mathrm{a}}$ & $55.7 \pm 2.07^{\mathrm{a}}$ & $65.6 \pm 1.43^{\mathrm{a}}$ & $16.1 \pm 0.55^{\mathrm{a}}$ & $45.9 \pm 2.38^{\mathrm{b}}$ & $50.1 \pm 2.52^{\mathrm{b}}$ & $35.3 \pm 2.25^{\mathrm{b}}$ \\
\hline Org & $80.6 \pm 1.33^{\mathrm{a}}$ & $30.5 \pm 2.57^{\mathrm{b}}$ & $20.8 \pm 2.05^{\mathrm{b}}$ & $25.7 \pm 1.42^{\mathrm{b}}$ & $18.7 \pm 0.54 \mathrm{a}$ & $48.4 \pm 2.56^{\mathrm{b}}$ & $30.3 \pm 2.51^{\mathrm{b}}$ & $20.7 \pm 2.17^{\mathrm{b}}$ \\
\hline Rt & $45.3 \pm 1.24^{\mathrm{b}}$ & $100.7 \pm 2.28^{\mathrm{a}}$ & $40.1 \pm 2.37^{\mathrm{a}}$ & $35.2 \pm 1.57^{\mathrm{b}}$ & $17.8 \pm 0.47^{\mathrm{a}}$ & $90.1 \pm 2.44^{\mathrm{a}}$ & $80.7 \pm 2.38^{\mathrm{a}}$ & $65.5 \pm 2.82^{\mathrm{a}}$ \\
\hline
\end{tabular}

Table 7. Nitrogen pools influenced by management strategy $\times$ season interaction in 2017 under conventional (Con), organic (Org) and reduced-tillage (Rt) management strategy. Notes: Means are shown that means with same letter within a season are not significantly different $(P=0.05)$. 


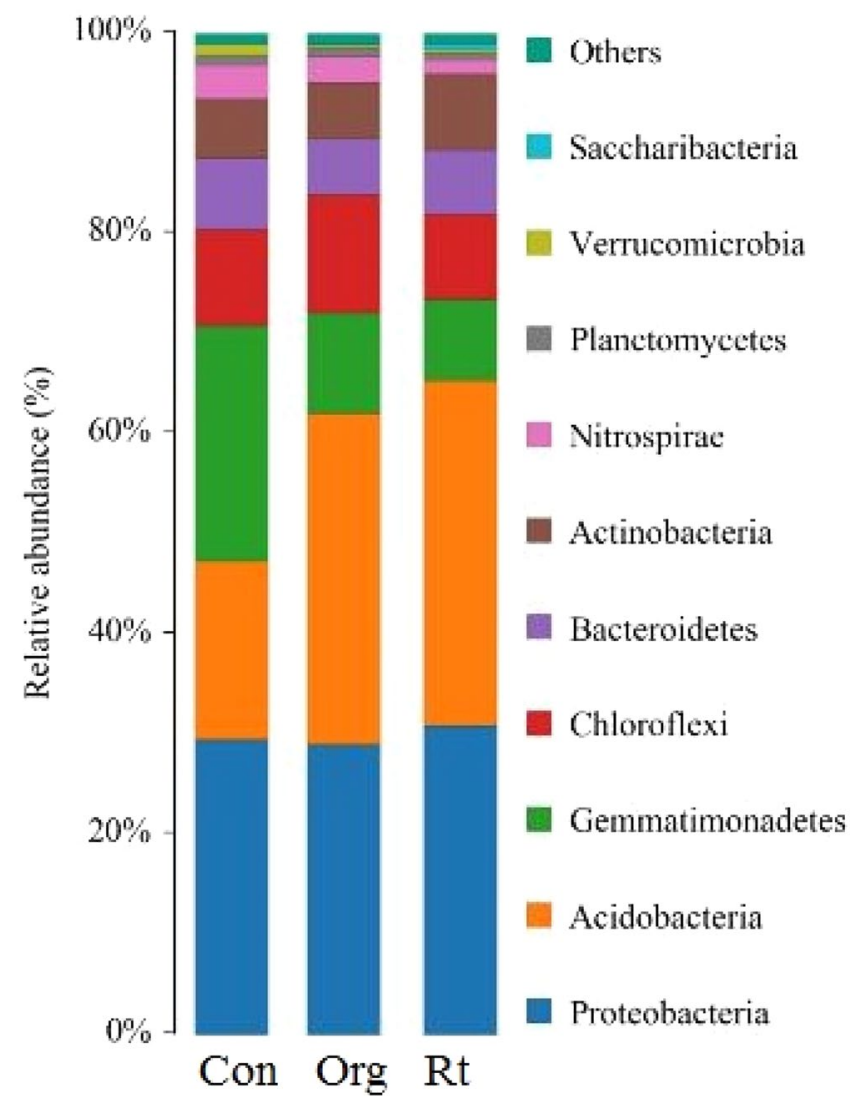

Figure 2. Comparison of the soil bacterial communities at the phylum level in the alfalfa-corn rotation under three management strategies. The relative abundance of the dominant bacterial groups in the soil differed depending on three management strategies. Relative abundance values are based on the proportional frequencies of DNA sequences that could be classified.

and Con management. In the Con management, apply fertilizer (Urea) increased the relative abundance of Gemmatimonadetes but decreased the relative abundance of Proteobacteria.

\section{Discussion}

Results support the our hypothesis that Rt would increase soil quality which maintains yields among the three management strategies. In this study, SOC and N pools were higher in forth year under forage-based rotations than in the first year after continuous corn and the highest increase in SOC and N occurred under Rt system, indicating that any reduction in soil disturbance can conserve SOC and N losses. Specifically, soil mineralizable $\mathrm{C}$ was higher under Rt management than under Org and Con management in the four years. Because of not tilled during corn cropping in continuous four years after alfalfa, soil mineralizable $\mathrm{C}$ under reduced soil disturbance may have contributed to the increase in SOC (Tables 3-5). These results partially support our hypothesis that reduced-tillage and organic management increase SOC and N pools compared with the conventional system. Although not statistically significant, it also showed greater contents of DOC and MBC under Rt than other management strategy (Tables 3 and 4). Some studies have reported that Rt strategy was contribute to SOC accumulation by increasing the amount and diversity of root and soil microbial biomass, crop residue inputs, root exudates, and rhizodeposits ${ }^{2,19}$. Our results here also suggested that Rt strategy was significantly and positively correlated with soil bacterial communities, which was higher the relative abundance of the dominant bacterial groups than in the Con strategy. This conclusion is supported by previous studies ${ }^{35,36}$.

Changes in labile $\mathrm{C}$ and $\mathrm{N}$ pools in response to alternative management strategy in this study were similar to those reported in previous studies. Previous studies have shown that crop rotations under alternative management strategy may double SOC and $\mathrm{N}$ pools ${ }^{6,37,38}$. In the present study, greater DOC, MBC, inorganic $\mathrm{N}$ were observed in forth year compared to first year, probably due to management change from monocropping to rotational strategy and reduced soil disturbance, the presence of alfalfa crop in the rotation, and organic manure fertilization to improve soil fertility of the low-fertile soil in the cold, semiarid environment (Table 1). Based on the weather in 2015 and 2016 year, much more precipitation ( 32.4 and $30.2 \mathrm{~mm}$ ) were comparative to the average value $(28.1 \mathrm{~mm})$ so that more lodging reported by Guo et al..$^{39}$ occurred in both years. So both years were conducive to the growth. These weather variations were part of the reasons of annual total yield differences of the same managements, and the interaction (management $\times$ year) on aboveground biomass yield. Some studies have reported that increased water saturation will influence soil enzyme activities ${ }^{40}$, mineralization of organic matter and so on $^{41,42}$. In this study, all management strategy showed net gains in SOC and N pools such as mineralizable 


\begin{tabular}{|l|l|l|l|l|}
\hline \multirow{2}{*}{} & \multicolumn{4}{|l}{ Biomass $\left(\mathrm{Mg} \mathrm{ha}^{-1}\right)$} \\
\cline { 2 - 5 } & $\mathbf{2 0 1 4}$ & $\mathbf{2 0 1 5}$ & $\mathbf{2 0 1 6}$ & $\mathbf{2 0 1 7}$ \\
\hline Con & $10.21 \pm 0.13 \mathrm{a}$ & $10.82 \pm 0.10 \mathrm{~b}$ & $10.92 \pm 0.18 \mathrm{~b}$ & $10.43 \pm 0.15 \mathrm{c}$ \\
\hline Org & $10.72 \pm 0.16 \mathrm{a}$ & $10.61 \pm 0.11 \mathrm{~b}$ & $10.53 \pm 0.11 \mathrm{~b}$ & $11.22 \pm 0.12 \mathrm{~b}$ \\
\hline Rt & $10.91 \pm 0.10 \mathrm{a}$ & $11.22 \pm 0.15 \mathrm{a}$ & $11.77 \pm 0.16 \mathrm{a}$ & $12.32 \pm 0.18 \mathrm{a}$ \\
\hline
\end{tabular}

Table 8. Aboveground biomass (from 2014 to 2017 year) of grain yield of corn under conventional (Con), organic (Org) and reduced-tillage (Rt) management. Notes: Means are shown that means with same letter within a year are not significantly different $(P=0.05)$.

\begin{tabular}{|l|l|l|l|l|l|l|l|}
\hline & Kindom & Phylum & Class & Order & Family & Genus & Species \\
\hline Con & 1 & 20 & 65 & 100 & 179 & 266 & 189 \\
\hline Org & 1 & 22 & 74 & 114 & 192 & 291 & 217 \\
\hline Rt & 1 & 23 & 75 & 111 & 196 & 294 & 225 \\
\hline
\end{tabular}

Table 9. Soil microbial community under conventional (Con), organic (Org) and reduced-tillage (Rt) management.

$\mathrm{C}$ and N, MBC, MBN, DOC, and DON during four years (Tables 4 and 5). During the experiment, it showed a benefit in responses of SOC and N pools, and comparable crop yield among management strategy indicates potential for alternative soil fertility strategies to conserve SOC and $\mathrm{N}$ and maintain yields.

The similar SOC for Org and Con strategy, indicate possible benefits due to the use of manure in the Org management may take longer than one four-year rotation cycle in perennial forage-based rotations. Long-term studies have shown greater SOC for Org management compared to Con management ${ }^{10,43}$. In the present study, Org management showed greater rates of mineralization and microbial uptake of SOC compared to Con and Rt strategy (Tables 6 and 7). Seasonal trends in mineralizable and inorganic $\mathrm{N}$ contents were different for the management strategy, indicating that inorganic fertilizer may have contributes to increased $\mathrm{N}$ pools in the Con strategy. The application of nitrogen fertilizers combined with soil disturbance accelerates $\mathrm{N}$ mineralization, contributing to increased inorganic $\mathrm{N}$ content in the soil ${ }^{17}$. A possible mechanisms responsible for results have reported that Rt system decreased tillage times, reduced the mechanical destruction to soil aggregates, improved the soil physical and chemical properties and increase soil water storage, which can significantly increases crop yields reported by He et al. ${ }^{44,45}$.

All management strategy showed an increase in DOC and MBC, and a decrease in DON and MBN, indicating that DOC was mainly root exudates and crop rhizosphere microbial communities, which may have been impacted by growing crops in the rotation. Org system showed consistently low soil inorganic $\mathrm{N}$ throughout the study (Tables 4 and 5) and followed different seasonal trends (Tables 6 and 7) compared to other management strategy, indicating differences for organic and chemical fertilizers in soil $\mathrm{N}$ accumulation. In fact, soil microbial biomass have been shown to be more sensitive than soil biochemical properties to soil disturbance resulting from intensive tillage practices ${ }^{46,47}$. We noted that the microbial community was also benefited, with greater microbial productivity, saprotrophic bacteria, and gram-positive bacteria and greater efficiency of substrate utilization per unit microbial biomass as reported by Ghimire et al. ${ }^{12}$. Management strategy showed differences in SOC and $\mathrm{N}$ pools that combined with changes in soil microbiotic properties and root biomass production reported in previous studies $^{2,13}$, suggest an interactions between soil amendment type (chemical vs. organic) and soil tillage strategy.

In Org system in this study, higher $\mathrm{N}$ use efficiency is also indicated by comparable yields between Con and Org strategy in all year with different contents of mineralizable and inorganic N (Table 8). This result corroborates with comparable amounts of tissue $\mathrm{N}$ content and crop production between Con and Org strategy in a crop rotation study in Iow $\mathrm{a}^{6}$ and indicates agronomic and soil quality benefits of Org management compared with Con strategy. However, a longer-term research are needed to explore management strategy with crop rotations and their potential to improve agronomic and soil quality benefits, specifically differences in responses of labile and total $\mathrm{C}$ and $\mathrm{N}$ under alternative management strategy.

\section{Conclusion}

In the northeast of China, perennial forage-based rotations play an important role for maintaining soil organic matter and crop productivity. SOC and N pools, and crop production were considerably affected by conventional, organic, and reduced-tillage management in this cold, wet, and low fertility environment. Despite consistent increases in labile $\mathrm{C}$ and $\mathrm{N}$ and comparable yield across management strategy, differences in soil $\mathrm{C}, \mathrm{N}$ pools and microbial community in experiment year indicate that conventional, organic, and reduced-tillage management impact soil environments differently to mediate crop production. Reduced-tillage and organic strategy can be considered good options to improve agroecosystem performance in highly depleted soils of northeast region, since they produced comparable forage biomass and corn yield to conventional management system in five to six years and increased SOC and N pools. Longer-term monitoring will improve our understanding of relationships among soil $\mathrm{C}$ and $\mathrm{N}$ pools, seasonal and interannual dynamics, and crop performance under alternative management strategy in perennial forage-based rotations. The effects of the perennial forage-based rotations on fungal community structure and diversity under management strategy need further study. 


\section{Data availability}

The dataset of our study is available from the first author on reasonable request.

Received: 1 February 2019; Accepted: 4 November 2019;

Published online: 19 November 2019

\section{References}

1. Rajan, G., Urszula, N., Prakriti, B., Augustine, K. O. \& Jay, B. N. Soil organic matter, greenhouse gases and net global warming potential of irrigated conventional, reduced-tillage and organic cropping systems. Nutrient Cycling in Agroecosystems. 107, 46-49 (2017).

2. Ghimire, R., Norton, J. B. \& Pendall, E. Alfalfa-grass biomass, soil organic carbon, and total nitrogen under different management approaches in an irrigated agroecosystem. Plant Soil. 374, 173-184 (2014).

3. Wander, M. M., Traina, S. J., Stinner, B. R. \& Peters, S. E. Organic and conventional management effects on biologically-active soil organic-matter pools. Soil Sci. Soc. Am. J. 58, 1130-1139 (1994).

4. Meyer, D. \& Helm, J. Alfalfa management in North Dakota. North Dakota State University (1994).

5. Ghimire, R. et al. Long-term farming systems research in the central High Plains. Renew. Agric. Food Syst. 28, 183-193 (2013).

6. Delate, K. \& Cambardella, C. A. Agroecosystem performance during transition to certified organic grain production. Agron. J. 96, $1288-1298$ (2004).

7. Poudel, D. D., Horwath, W. R., Lanini, W. T., Temple, S. R. \& Bruggen, A. H. C. Comparison of soil N availability and leaching potential, crop yields and weeds in organic, low-input and conventional farming systems in northern California. Agric. Ecosyst. Environ. 90, 125-137 (2002).

8. Carr, P., Madera, P., Creamera, N. G. \& Beeby, J. S. Overview and comparison of conservation tillage practices and organic farming in Europe and North America. Renew. Agric. Food Syst. 27, 2-6 (2012).

9. Franzluebbers, A. J. Integrated crop-livestock systems in the southeastern USA. Agron.J. 99, 361-372 (2007).

10. Halvorson, A. D., Wienhold, B. J. \& Black, A. L. Tillage, nitrogen, and cropping system effects on soil carbon sequestration. Soil Sci. Soc. Am. J. 66, 906-912 (2002).

11. Qin, R. J., Stamp, P. \& Richner, W. Impact of tillage on root systems of winter wheat. Agron.J. 96, 1523-1530 (2004).

12. Ghimire, R., Norton, J. B., Stahl, P. D. \& Norton, U. Soil microbiotic properties under irrigated organic and reduced-tillage crop and forage production systems. Plos one. 9(8), e103901 (2014).

13. Kramer, A. W., Doane, T. A., Horwath, W. R. \& Kessel, C. Combining fertilizer and organic inputs to synchronize N supply in alternative cropping systems in California. Agric.Ecosyst.Environ. 91, 233-243 (2002).

14. Entz, M. H. et al. Potential of forages to diversify cropping systems in the Northern Great Plains. Agron J. 94, 240-250 (2002).

15. Posner, J. L., Baldock, J. O. \& Hedtcke, J. L. Organic and conventional production systems in the Wisconsin Integrated Cropping Systems Trials: I. Productivity 1990-2002. Agron. J. 100, 253-260 (2008).

16. Drinkwater, L. E., Wagoner, P. \& Sarrantonio, M. Legume-based cropping systems have reduced carbon and nitrogen losses. Nature. 136, 262-265 (1998).

17. Allen, V. G., Baker, M. T., Segarra, E. \& Brown, C. P. Integrated irrigated crop-livestock systems in dry climates. Agron. J. 99, 346-360 (2007).

18. Louarn, G. et al. The amounts and dynamics of nitrogen transfer to grasses differ in alfalfa and white clover-based grass-legume mixtures as a result of rooting strategies and rhizodeposit quality. Plant Soil. 389, 289-305 (2015).

19. Kramer, A. W., Doane, T. A., Horwath, W. R. \& Kessel, C. Combining fertilizer and organic inputs to synchronize N supply in alternative cropping system in California. Agric. Ecosyst.Environ. 91, 233-243 (2002).

20. Allen, V. G., Baker, M. T., Segarra, E. \& Brown, C. P. Integrated irrigated crop-livestock system in dry climates. Agron. J. 99, 346-360 (2007).

21. Guo, S., Wu, J. \& Dang, T. Effects of crop rotation and fertilization on aboveground biomass and soil organic carbon in semiarid region. Scient. Agric. Sinica. 41, 744-751 (2008).

22. Fu, X., Wang, J., Sainju, U. M. \& Liu, W. Z. Soil carbon fractions in response to Longterm crop rotations in the Loess Plateau of China. Soil Sci. Soc. Am. J. 81, 503-513 (2017).

23. Olsen, S.R., Cole, C.V., Watanabe, F.S. \& Dean, L.A. Estimation of Available Phosphorous in Soil by Extraction with Sodium Bicarbonate. USDA circular 939. USAD, Washington, D.C (1954).

24. Conservation Technology Information Center (CTIC). Tillage type definitions, http://www.ctic.purdue.edu/resourcedisplay/322/. Accessed 05 Aug, (2016).

25. Hossain, M. S. et al. Productivity and soil fertility of the rice-wheat system in the high Ganges River floodplain of Bangladesh is influenced by the inclusion of legumes and manure. Agric. Ecosyst. Environ. 218, 40-52 (2016).

26. Jahan, M. A. H. S., Hossain, A., Sarker, M. A. R., Teixeira, J. A. \& Ferdousi, M. N. S. Productivity impacts and nutrient balances of an intensive potato-mungbean-rice crop rotation in multiple environments of Bangladesh. Agric. Ecosyst. Environ. 218, 79-97 (2016).

27. Moore, J. M., Klose, S. \& Tabatabai, M. A. Soil microbial biomass carbon and nitrogen as affected by cropping systems. Biol. Fertil. Soils. 31, 200-210 (2000).

28. Franzluebbers, A. J., Hons, F. M. \& Zuberer, D. A. Soil organic carbon, microbial biomass, and mineralizable carbon and nitrogen in sorghum. Soil Sci.Soc.Am.J. 59, 460-466 (1995).

29. Gee, G. W. \& Bauder, J. W. Particle-size analysis. In A. Klute, editor, Methods of soil analysis, physical and mineralogical methods Part 1. 2 ed. Agron. Monogr. 9. ASA and SSSA, Madison, WI. 383-411(1986).

30. Thomas, G. W. Soil pH and soil acidity. In Sparks, D. L., editor, Methods of soil analysis, Part 3: Chemical methods. Agronomy monograph 9. ASA, SSSA, Madison, WI. 475-490 (1996).

31. Sherrod, L. A., Dunn, G., Peterson, G. A. \& Kolberg, R. L. Inorganic carbon analysis by modified pressure-calcimeter method. Soil Sci. Soc. Am. J. 66, 299-305 (2002).

32. Osunbitan, J. A., Oyedele, D. J. \& Adekalu, K. O. Tillage effects on bulk density, hydraulic conductivity and strength of a loamy sand soil in southwestern Nigeria. Soil and Tillage Research 82, 57-64 (2005).

33. Zhou, J. et al. Influence of 34 years of fertilization on bacterial communities in an intensively cultivated black soil in northeast China. Soil. Biol. Biochem. 90, 42-51 (2015).

34. Li, Q., Song, X., Gu, H. \& Gao, F. Nitrogen deposition and management practices increase soil microbial biomass carbon but decrease diversity in Moso bamboo plantations. Sci. Rep. 6, 628-235 (2016).

35. Sainju, U. M., Caesar-TonThat, T., Lenssen, A. W., Evans, R. G. \& Kolberg, R. Long-term tillage and cropping sequence effects on dryland residue and soil carbon fractions. Soil Sci. Soc. Am. J. 71, 1730-1739 (2007).

36. Orr, C. H., James, A., Leifert, C., Cooper, J. M. \& Cummings, S. P. Diversity and activity of free-living nitrogen-fixing bacteria and total bacteria in organic and conventionally managed soils. Appl. Environ. Microbiol. 77, 911-919 (2011).

37. Marriott, E. E. \& Wander, M. M. Total and labile soil organic matter in organic and conventional farming systems. Soil Sci. Soc. Am. J. 70, 950-959 (2006). 
38. McDaniel, M. D., Tiemann, L. K. \& Grandy, A. S. Does agricultural crop diversity enhance soil microbial biomass and organic matter dynamics? A meta-analysis. Ecological Applications. 24, 560-570 (2014).

39. Guo, E. L., Zhang, J. Q., Wang, Y. F., Si, H. \& Zhang, F. Waterlogging disasters are one of the most destructive meteorological disasters, which lead to crop yield reduction and cause a great threat to humanity and economic structure. Natural Hazards $\mathbf{8 3}$, 17-47 (2016).

40. Vida, K., Fayez, R. \& Mohammad, A. G. Tillage effects on soil microbial biomass, SOM mineralization and enzyme activity in a semi-arid Calcixerepts. Agriculture, Ecosystems and Environment 232, 73-84 (2016).

41. Geisseler, D. \& Horwath, W. R. Short-term dynamics of soil carbon, microbial biomass, and soil enzyme activities as compared to longer-term effects of tillage in irrigated row crops. Biol. Fertil. Soils. 46, 65-72 (2009).

42. Laudicina, V. A., Badalucco, L. \& Palazzolo, E. Effects of compost input and tillage intensity on soil microbial biomass and activity under Mediterranean conditions. Biol. Fertil. Soils. 47, 63-70 (2011).

43. Reganold, J. P., et al Fruit and soil quality of organic and conventional strawberry agroecosystems. Plos one. 5(10), https://doi. org/10.1371/annotation/1eefd0a4-77af-4f48-98c3-2c5696ca9e7a (2010).

44. He, J., Li, H. W. \& Gao, H. W. Subsoiling effect and economic benefit under conservation tillage mode in Northern China. Transactions of the Chinese Society of Agricultural Engineering. 22, 62-67 (2006).

45. He, J. et al. The adoption of annual subsoiling as conservation tillage in dryland maize and wheat cultivation in northern China. Soil Tillage Res. 94, 493-502 (2007).

46. Roldán, A., Salinas-García, J. R., Alguacil, M. M. \& Caravaca, F. Changes in soil enzyme activity, fertility, aggregation and C sequestration mediated by conservation tillage practices and water regime in a maize field. Appl. Soil Ecol. 30, 11-20 (2005).

47. Madejón, E., Moreno, F., Murillo, J. M. \& Pelegrín, F. Soil biochemical response to long-term conservation tillage under semi-arid Mediterranean conditions. Soil Tillage Res. 94, 346-352 (2007).

\section{Acknowledgements}

This work was supported by the projects CARS-34 and YS16B09. We are grateful to Yuexue Zhang for providing seeds and Xue Wang, Guili Di and Liwen Shan for their assistance in laboratory and others for many helpful comments.

\section{Author contributions}

J.S. conceived and designed the experiments, R.F., X.L. and D.Q. (Dequan Sun) performed the experiments and analyzed the data, J.S. and Q. Zhang wrote the manuscript. All authors contributed to the discussion of the original idea.

\section{Competing interests}

The authors declare no competing interests.

\section{Additional information}

Correspondence and requests for materials should be addressed to D.S.

Reprints and permissions information is available at www.nature.com/reprints.

Publisher's note Springer Nature remains neutral with regard to jurisdictional claims in published maps and institutional affiliations.

(c) (i) Open Access This article is licensed under a Creative Commons Attribution 4.0 International (c) License, which permits use, sharing, adaptation, distribution and reproduction in any medium or format, as long as you give appropriate credit to the original author(s) and the source, provide a link to the Creative Commons license, and indicate if changes were made. The images or other third party material in this article are included in the article's Creative Commons license, unless indicated otherwise in a credit line to the material. If material is not included in the article's Creative Commons license and your intended use is not permitted by statutory regulation or exceeds the permitted use, you will need to obtain permission directly from the copyright holder. To view a copy of this license, visit http://creativecommons.org/licenses/by/4.0/.

(c) The Author(s) 2019 